\title{
VEGF-A and PD-L1 Immunoexpression Association with Meningioma Histopathology Grade
}

\author{
Yunnica, ${ }^{1,2}$ Afiati, ${ }^{2}$ Hermin Aminah Usman, ${ }^{2}$ Bethy Surjawathy Hernowo ${ }^{2}$ \\ ${ }^{1}$ Anatomical Pathology Study Program, Faculty of Medicine, Universitas Padjadjaran/Dr. Hasan Sadikin \\ General Hospital, Bandung, Indonesia, ${ }^{2}$ Department of Anatomical Pathology, Faculty of Medicine, \\ Universitas Padjadjaran/Dr. Hasan Sadikin General Hospital, Bandung, Indonesia
}

\begin{abstract}
Histopathology grade of meningioma is one of the most common factors determining the prognosis and affects the risk of recurrence and aggressiveness of the tumor. Biological factors related to histopathological grade are vascular endothelial growth factor A (VEGF-A) and programmed death-ligand 1 (PD-L1). This research aimed to understand the association between VEGF-A and PD-L1 with meningioma histopathology grade. This is in vivo research on 60 paraffin blocks of meningioma cases at Dr. Hasan Sadikin General Hospital Bandung from April to November 2018. Paraffin block samples consist of grade I (30), grade II (15), and grade III (15) meningioma. Immunohistochemical staining of VEGF-A and PD-L1 performed to all samples. Data analyzed using the chi-square test with SPSS version 24.0 for Windows. The result shows a significant association between VEGF-A and PD-L1 immunoexpression with meningioma histopathology grade. PD-L1 is the most potent factor that influenced the histopathology grade of meningioma. The study concluded that the histopathology grade of meningiomas influenced by angiogenesis and immune checkpoints. VEGF-A and PD-L1 immunoexpression in meningioma considered as a factor that influences the aggressiveness of meningioma.
\end{abstract}

Key words: Histopathology grade, meningioma, PD-L1, VEGF-A

\section{Hubungan Imunoekspresi VEGF-A dan PD-L1 dengan Derajat Histopatologi Meningioma}

\begin{abstract}
Abstrak
Derajat histopatologi meningioma merupakan salah satu faktor yang paling umum menentukan prognosis serta memengaruhi risiko rekurensi dan agresivitas tumor. Faktor biologi yang berhubungan dengan derajat histopatologi adalah vascular endothelial growth factor A (VEGF-A) dan programmed death-ligand 1 (PD-L1). Penelitian ini bertujuan mengetahui hubungan imunoekspresi VEGF-A dan PD-L1 dengan derajat histopatologi meningioma. Penelitian in vivo dilakukan pada 60 blok parafin kasus meningioma di Departemen Patologi Anatomi RSUP Dr. Hasan Sadikin Bandung dari April hingga November 2018. Sampel blok parafin terdiri atas meningioma derajat I (30), derajat II (15), dan derajat III (15). Pulasan imunohistokimia VEGF-A dan PD-L1 dilakukan terhadap semua sampel. Data dianalisis menggunakan uji chi-square dengam SPSS versi 24.0 untuk Windows. Hasil penelitian menunjukkan bahwa terdapat hubungan yang signifikan antara VEGF-A dan PD-L1 dengan derajat histopatologi meningioma. PD-L1 merupakan faktor paling kuat yang memengaruhi derajat histopatologi meningioma. Simpulan penelitian ini adalah derajat histopatologi meningioma dipengaruhi oleh faktor angiogenesis dan immune check point. Imunoekspresi VEGF-A dan PD-L1 pada meningioma dapat dipertimbangkan sebagai faktor yang memengaruhi agresivitas meningioma.
\end{abstract}

Kata kunci: Derajat histopatologi, meningioma, PD-L1, VEGF-A

Received: 19 November 2018; Revised: 1 August 2019; Accepted: 5 September 2019; Published: 31 December 2019 


\section{Introduction}

Meningioma is the most common intracranial tumor from the meningothelial cells of the arachnoid layer., ${ }^{1,2}$ Thirty-six percent of all primary central nervous tumor is meningioma. ${ }^{2}$ Meningioma is the most common intracranial tumor in the USA and Korea. The incidence of meningioma in the USA is $36 \%$ and $37.3 \%$ in Korea. ${ }^{1,3}$ The median age of patients with meningioma is 65 years. Females are at higher risk than male, with a female:male ratio of nearly 2:1.1. ${ }^{4}$ Groups who have lower incidences of meningiomas, specifically men and children, tend to have more aggressive tumors when they do occur. ${ }^{5,6}$

The recurrence of meningioma is generally varies depending on the histopathology grade of meningioma, i.e., $12 \%$ in grade I, 29-40\% in grade II, and 50-94\% in grade III. ${ }^{1,7}$ The recurrence of meningiomas is strongly associated with histopathological grade. The mortality rate of atypical meningioma grade II and anaplastic meningioma grade III in 5 years are $21 \%$ and $68 \%$. The mean survival rate of anaplastic meningioma is 1.5 years. $^{8}$ Malignant meningiomas constitute about $1 \%$ to $3 \%$ of meningiomas. ${ }^{9}$

The histopathology grade is one of the most critical indicators in determining prognosis. ${ }^{1}$ The histopathology grade of meningioma determined by tumor morphology, proliferation index, and invasion of brain tissue. ${ }^{8}$ Variants of meningiomas are divided based on the risk of recurrence and aggressive of the tumor. ${ }^{1}$ The aggressiveness of meningioma determined by mitotic index, other proliferation markers, cell differentiation, genetic in tumor cells, and morphological features of pathology. Morphological features of meningioma are essential in predicting the behavior meningioma. ${ }^{10-12}$ Grade I is meningioma with a low risk of recurrence and is less aggressive. While grade II, III and any subtype of meningiomas with a high proliferation index are meningiomas with a high risk of recurrence and aggressive. ${ }^{1}$

Meningioma is a high vascularization tumor requiring neovascularization for its growth. ${ }^{13}$ The secretion of angiogenesis factors-such as vascular endothelial growth factor A (VEGF-A)can induce neovascularization as one of the necessary conditions for meningioma growth. Angiogenesis in meningiomas is associated with an aggressive tumor. Angiogenesis is significantly associated with considerable tumor growth, shorter recurrence, and survival rates in meningioma. ${ }^{14-18}$

VEGF-A affects the immunosuppressive tumor microenvironment by inhibiting the maturation of dendritic cells. It stimulates the immunoexpression of programmed death-ligand 1 (PD-L1) in tumor cells. VEGF-A interferes with the cancer-immunity cycle through stages, namely inhibiting the maturation of dendritic cells, disrupting infiltration of T cells into tumors, and promoting immunosuppressive tumor microenvironment. ${ }^{19}$

PD-L1 expressed in high-grade meningioma, suggested to have a significant role in tumor aggressivity. ${ }^{8}$ Immunosuppressive effect tumor cells on immune surveillance caused by tumor cells expressing PD-L1 create the programmed death-1 (PD-1)/PD-L1 axis, which is the convergence of PD-1 in $\mathrm{T}$ cells with ligand namely PD-L1 in tumor cells. It is called an immune checkpoint. It causes cytotoxic $\mathrm{T}$ cells weakness. ${ }^{20,21}$

Currently, anti-VEGF target therapy usually used by bevacizumab. Bevacizumab is a monoclonal antibody at VEGF receptors interferes with binding and signal transduction needed for tumor vascularization. It resulting in a regression of blood supply to the tumor..$^{22,23}$ Bevacizumab has conducted phase II clinical trials in patients with recurrent or progressive meningiomas. ${ }^{24}$ Targeted anti-VEGF therapy is a promising avenue for meningioma because of robust pharmaceutical development and VEGF expression. $^{25}$ Angiogenesis may represent a target for therapies aimed at reducing the growth of inoperable meningioma or recurrence risk of totally resected tumor. ${ }^{26}$

The intracranial lymphatic system is associated with dural sinus, which promises immunotherapy to meningioma. The Gelerstein et al.'s ${ }^{27}$ case report study, show the use of immunotherapy (anti-PD-1/anti-PD-L1) reduces tumor size in meningioma. ${ }^{28}$ At present the antiPD-1 immunotherapy used is nivolumab. Phase II clinical trials in the evaluation of PD-1 checkpoint blockade with nivolumab carried out in grade II/ III meningioma. ${ }^{29}$

This study aimed to describe the association between VEGF-A and PD-L1 immunoexpression with histopathological meningioma grade.

\section{Methods}

The time of study took place from April to November 2018. Samples were taken from 
patients registered at Dr. Hasan Sadikin General Hospital Bandung and obtained 60 samples. They diagnosed histopathologically with meningioma from January 2013 to August 2018 and classified in the group of grade I (30 samples), grade II (15 samples), and grade III (15 samples). The tumor cells collected through operation and fixated in the paraffin block. This is an in vivo study using samples from paraffin blocks prepared for immunohistochemistry (IHC) analysis. IHC analysis was performed based on the protocol provided by the anatomical pathology laboratory. The slides visualized under the Olympus BX53F microscope.

Mouse monoclonal antibody VEGF-A SC7269 (Santa Cruz Biotechnology, USA) with 1:100 dilution and rabbit monoclonal antibody clone 28-8 (ab205921) (Abcam, USA) with 1:100 dilution used in standard immunohistochemistry staining procedure. The positive result was shown/visualized as brown staining on the tumor cell. Analysis of VEGF-A and PD-L1 immunoexpression evaluated by brown staining assessed on the tumor cell membrane and or cytoplasm, respectively. The staining intensity measured under the microscope converted into a score. Intensity score explained as o (null) represents blank samples or no stained tumor cells; score $1+$ for positive weak; score $2+$ for moderate positive; and score $3+$ for the strong positive. Distribution score explained as score o (null) represent no stained tumor cells; score $1+$ for less than $20 \%$ colored/stained tumor cells; score $2+$ for $20 \%-50 \%$ stained tumor cells; score $3^{+}$for $51 \%-80 \%$ stained tumor cells, and lastly score $4+$ represent $>80 \%$ of stained tumor cells. Histoscore (distribution $\times$ intensity) was interpreted as $\geq 6=$ high and $<6=$ low. IHC staining result was examined by two experts in the IHC technique using light microscope Olympus BX53F.14,19
This study used a retrospective analytic observational method with a cross-sectional study design. All data were analyzed using the chisquare test with a $\mathrm{p}$ value $<0.05$ of a significant level then proceed with SPSS version 24.0 for Windows.

Ethical clearance approved by Research Ethics Committee, Universitas Padjadjaran, with assessment number: 997/UN6.KEP/EC/2018.

\section{Results}

Table 1 showed the characteristics of subjects such as age and sex. The incidence of meningioma was more frequent among females (73\%) than males (27\%).

Table 2 showed no significant difference between each character of subjects on the histopathology grade of the meningioma group ( $\mathrm{p} \geq 0.05$ ).

Table 3 showed the significant association between the VEGF-A immunoexpression and histopathology grade of meningioma $(\mathrm{p}=0.0001)$. It also showed a significant association between the PD-L1 immunoexpression and histopathology grade of meningioma ( $\mathrm{p}=0.0001)$.

Table 4 showed that there are association VEGF-A and PD-L1 with histopathology grade of meningioma, and PD-L1 is the strongest factor that influences the histopathology grade of meningioma $(\mathrm{p}=\mathrm{o.001})$.

Table 1 Characteristics of the Subjects

\begin{tabular}{lc}
\hline Age and Sex & $\mathbf{n}=\mathbf{6 0}$ \\
\hline $\begin{array}{l}\text { Age (years) } \\
\text { Mean }\end{array}$ & 42 \\
Sex & \\
Males & $16(27 \%)$ \\
Females & $44(73 \%)$ \\
\hline
\end{tabular}

Table 2 Homogeneity Test of the Subjects

\begin{tabular}{lcccc}
\hline \multirow{2}{*}{ Age and Sex } & \multicolumn{2}{c}{ Histopathology Grade of Meningioma } & \multirow{2}{*}{ p Value } \\
\cline { 2 - 4 } & Grade I (n=30) & Grade II (n=15) & Grade III (n=15) & \\
\hline Age (years) & 43 & 41 & 40 & 0.614 \\
Mean & & & & \\
Sex & 6 & 4 & 6 & 0.360 \\
Males & 24 & 11 & 9 & \\
Females & & & & \\
\hline
\end{tabular}

Note: for categorical data, the $\mathrm{p}$ value analyzed with the chi-square test, but for numeric data, the $\mathrm{p}$ value analyzed with the ANOVA test. The value of significance based on a $\mathrm{p}$ value $<0.05$ 
Table 3 VEGF-A and PD-L1 Histoscore Data on Histopathology Grade of Meningioma Group

\begin{tabular}{lcccc}
\hline \multirow{2}{*}{ Variables } & \multicolumn{2}{c}{ Histopathology Grade of Meningioma } & \multirow{2}{*}{ p Value } \\
\cline { 2 - 4 } & Grade I (n=30) & Grade II (n=15) & Grade III (n=15) & \\
\hline Histoscore VEGF-A & 20 & 3 & 2 & 0.0001 \\
Low & 10 & 12 & 13 & \\
High & & & & 0.0001 \\
Histoscore PD-L1 & 23 & 4 & 2 & \\
Low & 7 & 11 & 13 & \\
High & &
\end{tabular}

Note: for categorical data, the $\mathrm{p}$ value analyzed with the chi-square test. The value of significance based on a $\mathrm{p}$ value $<0.05$

Table 4 Association VEGF-A and PD-L1 Immunoexpression with Histopathology Grade of Meningioma

\begin{tabular}{lccc}
\hline Variables & Estimation Rate & Standard Error & p Value \\
\hline VEGF-A & -1.8 & 0.6 & 0.005 \\
PD-L1 & -2.2 & 0.6 & 0.001 \\
\hline
\end{tabular}

Note: for multivariate data, analysis using ordinal logistic regression analysis. The independent variable included in the logistic regression model is the independent variable, which in the bivariate analysis has a p value of less than 0.25 . The value of significance based on a $\mathrm{p}$ value $<0.05$

\section{Discussion}

The sample's characteristics are homogeneous; both age and sex are not confounding variables in this study. Hence the data is qualified for further statistical analysis.

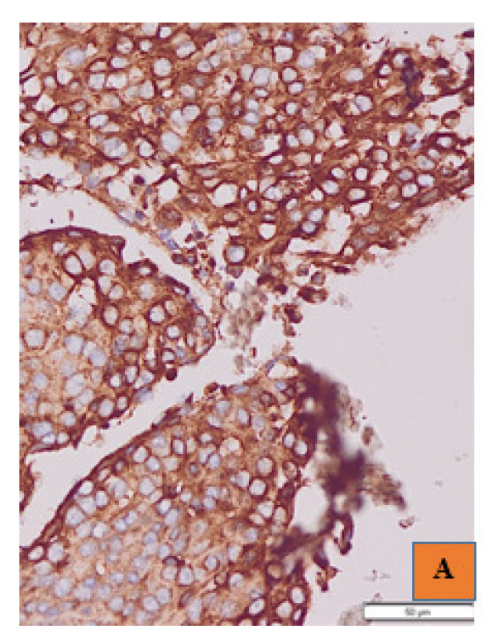

The VEGF-A plays an essential role in the regulation of tumor angiogenesis by promoting the migration, proliferation, and tube formation of endothelial cells. ${ }^{13}$ Angiogenesis has evaluated as a mechanism which influences meningioma growth and recurrence. ${ }^{30}$

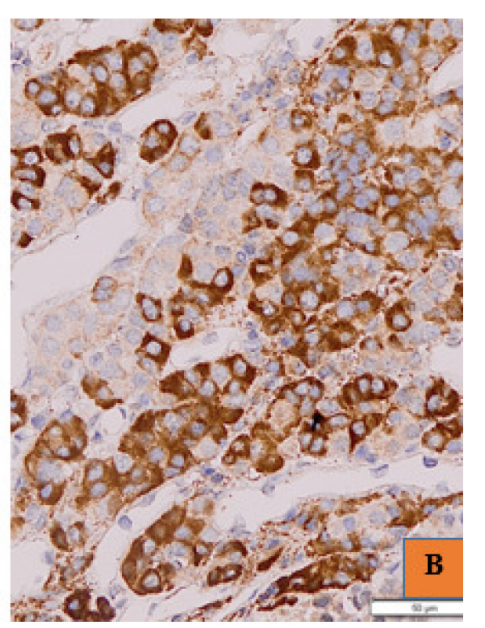

Figure VEGF-A and PD-L1 Imunoexpression of Meningioma with Strong Intensity (200 $\times$ Magnification)

Note: A=VEGF-A strong intensity. Tumor cells stained with VEGF-A antibody in the membrane and or cytoplasm; B=PD-L1 strong intensity. Tumor cells stained with PD-L1 antibody in the membrane and or cytoplasm 
This study performed a VEGF-A expression analysis on the meningioma histopathology grade. The result from IHC staining confirms that there were 12 of 15 with high VEGF-A immunoexpression in grade II dan 13 of 15 in grade III. There is a significant $(\mathrm{p}=0.0001)$ correlation between VEGF-A expression with meningioma histopathology grade. High immunoexpression VEGF-A is the result of high-grade meningioma. A study by Lee et al. ${ }^{14}$ stated that VEGF is an angiogenesis activator, which correlated with increased tumor grade.

Meningioma that proliferates caused hypoxia, which will stimulate hypoxia-inducible factor- $1 \alpha$ (HIF-1 $\alpha$ ) that stimulateVEGF-A.VEGF-A through the mitogen-activated protein kinase (MAPK) pathway cause endothelial cell proliferation. The phosphatidylinositol 3-kinase ( $\left.\mathrm{PiK}_{3}\right) /$ Akt pathway will inhibit endothelial cell apoptosis resulting in neovascularization differentiation. Neovascularization differentiation provides more nutrition to the tumor so that it will cause the tumor to proliferate. ${ }^{9}$ Neoangiogenesis shows that aggressive behavior is related to the high grade of histopathology. ${ }^{14}$

PD-L1 expressed in tumor cells binding to PD1 , which binds to $\mathrm{T}$ cells, and the engagement of PDL1 with PD-1 of T cell creates T cell dysfunction in tumor mass causes immunoresistence. The function of a tumor overexpressing PD-L1 is to protect itself from cytotoxic $\mathrm{T}$ cell (CD8+) mediated cell killing. ${ }^{20,21}$ It has been suggested that the immunosuppressive effects of PD-L1 expression contribute to the aggressive behavior of meningiomas, especially those of higher grade. ${ }^{8}$

This research also performed the PD-L1 immunoexpression analysis on meningioma histopathology grade. The result from IHC staining confirms that there were 11 out of 15 with high immunoexpression PD-L1 in grade II and 13 of 15 in grade III. According to chi-square analysis, there is a significant $(\mathrm{p}=0.0001)$ between the PD-L1 immunoexpression and high-grade meningioma. Strong PD-L1 immunoexpression found in high-grade meningioma. The study by $\mathrm{Du}$ et al. ${ }^{8}$ was similar to this study. Both showed PD-L1 expression increased in WHO anaplastic meningioma grade II and III. Du et al. ${ }^{8}$ showed that high-grade meningioma harbor an immunosuppressive tumor microenvironment and that increased Treg cells and elevated PD-L1 might contribute to the aggressive phenotype of these tumors.
Hypoxia stimulates HIF-1a, which can upregulate PD-L1. PD-L1 can stimulate Tregs cells, which will inhibit cytotoxic $\mathrm{T}$ cells so that immunoresistance occurs. ${ }^{31}$ The state of immunoresistance causes cytotoxic $\mathrm{T}$ cells to be unable to fight tumor cells so that they exhibit an aggressive phenotype related to high histopathological grade. ${ }^{8}$

VEGF-A not only promotes angiogenesis and vascular permeability, but it also contributes to an immunosuppressive tumor microenvironment. VEGF-A was reported to inhibit the maturation of dendritic cells, which cause differentiation of Treg cells and upregulate the immunoexpression of PD-L1 in tumor cells. ${ }^{19}$

There was an association between VEGF-A and PD-L1 with meningioma histopathology grade. PD-L1 is the most influential factor that influences the histopathology grade of meningioma $(\mathrm{p}=0.001)$. A study by Xue et al., ${ }^{19}$ confirmed that PD-L1 immunoexpression was significantly associated with the pathological grade, VEGF status, and KI-67 index in glioma.

\section{Conclusions}

There was a significant association between VEGF-A and PD-L1 with high-grade meningioma. Strong VEGF-A and PD-L1 immunoexpression positively associated with the likelihood of highgrade meningioma. Meningioma patients with II and III degrees recommended for VEGF-A and PD-L1 immunohistochemical examination to plan targeted therapy and immunotherapy.

\section{Conflict of Interest}

The authors declare no conflicts of interest.

\section{References}

1. Perry A, Louis DN, Budka H, von Deimling A, Sahm F, Rushing EJ, et al. Meningioma. In: Louis DN, Ohgaki H, Wiestler OD, Cavenee WK, editors. WHO classification of tumours of the central nervous system. $4^{\text {th }}$ Revised Edition. Geneva: WHO Press; 2016. p. 23245.

2. Osborn AG. Tumors of the meninges. In: Osborn AG, Hedlund GL, Salzman KL, editors. Osborn's brain: imaging, pathology and anatomy. $2^{\text {nd }}$ Edition. Salt Lake City: Elsevier Inc.; 2018. p. 659-94. 
3. Dho YS, Jung KW, Ha J, Seo Y, Park CK, Won YJ, et al. An updated nationwide epidemiology of primary brain tumors in Republic of Korea, 2013. Brain Tumor Res Treat. 2017;5(1):16-23.

4. Perry A. Tumours of the meninges. In: Love $\mathrm{S}$, Perry A, Ironside $\mathrm{J}$, Budka $\mathrm{H}$, editors. Greenfield's neuropathology. $9^{\text {th }}$ Edition. Boca Raton: CRC Press; 2015. p. 1803-27.

5. Schniederjan MJ. Biopsy interpretation of the central nervous system. $2^{\text {nd }}$ Edition. Philadelphia: Wolters Kluwer; 2018.

6. Ferlay J, Soerjomataram I, Dikshit R, Eser S, Mathers C, Rebelo M, et al. Cancer incidence and mortality worldwide: sources, methods and major patterns in GLOBOCAN 2012. Int J Cancer. 2015;136(5):E359-86.

7. Johnson MD. PD-L1 expression in meningiomas. J Clin Neurosci. 2018;57:4951.

8. Du Z, Abedalthagfi M, Aizer AA, McHenry AR, Sun HH, Bray MA, et al. Increased expression of the immune modulatory molecule PDL1 (CD274) in anaplastic meningioma. Oncotarget. 2015;6(7):4704-16.

9. Jeung JA. Malignant (anaplastic) meningiomas. In: Yachnis A, RiveraZengotita M, editors. Neuropathology: a volume in the high-yield pathology series. $1^{\text {st }}$ Edition. Philadelphia: Saunders; 2014. p. 144-5.

10. Velnar T. Meningiomas: pathology and clinical characteristics. In: Figueroa D, editor. Meningiomas: risk factors, treatment options and outcomes. New York: Nova Science Publishers, Inc.; 2016. p. 1-12.

11. Han MH, Kim CH. Riskfactors of meningioma. In: Figueroa D, editor. Meningiomas: risk factors, treatment options and outcomes. New York: Nova Science Publishers, Inc.; 2016. p. 13-28.

12. Poon MTC, Leung GKK. Surgical treatment for intracranial meningioma in the elderly. In: Figueroa D, editor. Meningiomas: risk factors, treatment options and outcomes. New York: Nova Science Publishers, Inc.; 2016. p. 137-40.

13. Wu Y, Lucia K, Lange M, Kuhlen D, Stalla GK, Renner U. Hypoxia inducible factor-1 is involved in growth factor, glucocorticoid and hypoxia mediated regulation of vascular endothelial growth factor-A in human meningiomas. $\mathrm{J}$ Neurooncol.
2014;119(2):263-73.

14. Lee SH, Lee YS, Hong YG, Kang CS. Significance of COX-2 and VEGF expression in histopathologic grading and invasiveness of meningiomas. APMIS. 2014;122(1):16-24.

15. Huang MC, van Loveren HR. Anatomy and biology leptomeninges. In: DeMonte DF, McDermott MW, Al-Mefty O, editors. AlMefty's meningiomas. $2^{\text {nd }}$ Edition. New York: Thieme Medical Publishers, Inc.; 2011. p. 25-34.

16. Claus EB, Morrison AL. Epidemiology of meningiomas. In: DeMonte DF, McDermott MW, Al-Mefty O, editors. Al-Mefty's meningiomas. ${ }^{\text {nd }}$ Edition. New York: Thieme Medical Publishers, Inc.; 2011. p. 35-39.

17. Morrison AL, Rushing E. Pathology of meningiomas. In: DeMonte DF, McDermott MW, Al-Mefty O, editors. Al-Mefty's meningiomas. ${ }^{\text {nd }}$ Edition. New York: Thieme Medical Publishers, Inc.; 2011. p. 40-50.

18. Ragel BT, Jensen RL. Molecular biology of meningiomas: tumorigenesis and growth. In: DeMonte DF, McDermott MW, Al-Mefty O, editors. Al-Mefty's meningiomas. $2^{\text {nd }}$ Edition. New York: Thieme Medical Publishers, Inc.; 2011. p. 51-62.

19. Xue S, HU M, Li P, Ma J, Xie L, Teng F, et al. Relationship between expression of PDL1 and tumor angiogenesis, proliferation, and invasion in glioma. Oncotarget. 2017;8(30):49702-12.

20. Alsaab HO, Sau S, Alzhrani R, Tatiparti K, Bhise K, Kashaw SK, et al. PD-1 and PD-L1 checkpoint signaling inhibition for cancer immunotherapy: mechanism, combinations, and clinical outcome. Front Pharmacol. 2017;8:561.

21. Momtaz P, Postow MA. Immunologic checkpoints in cancer therapy: focus on the programmed death-1 (PD-1) receptor pathway. Pharmgenomics Pers Med. 2014;7:357-65.

22. Lou E, Sumrall AL, Turner S, Peters KB, Desjardins A, Vredenburgh JJ, et al. Bevacizumab therapy for adults with recurrent/progressive meningioma: a retrospective series. J Neurooncol. 2012; 109(1):63-70.

23. Nassehi D. Intracranial meningiomas, the VEGF-A pathway, and peritumoral brain oedema. Dan Med J. 2013;60(4):B4626.

24. Franke AJ, Skelton WP IV, Woody LE, 
Bregy A, Shah AH, Vakharia K, et al. Role of bevacizumab for treatment-refractory meningiomas: a systematic analysis and literature review. Surg Neurol Int. 2018;9:133.

25. Gupta S, Bi WL, Dunn IF. Medical management of meningioma in the era of precision medicine. Neurosurg Focus. 2018;44(4):E3.

26. Barresi V. Angiogenesis in meningiomas. Brain Tumor Pathol. 2011;28(2):99-106.

27. Gelerstein E, Berger A, Jonas-Kimchi T, Strauss I, Kanner AA, Blumenthal DT, et al. Regression of intracranial meningioma following treatment with nivolumab: case report and review of the literature. J Clin Neurosci. 2017;37:51-3.

28. Imran H, Razia ET, Jawed HA, Nisar A, Choudry UK, Kumar A. Antibody targeted therapies in meningiomas: a critical review. J Surg Emerg Med. 2017;1(1):6.

29. Bi WL, Wu WW, Santagata S, Reardon DA, Dunn IF. Checkpoint inhibition in meningiomas. Immunotherapy. 2016;8(6): 721-31.

30. Dharmalingam P, Roopesh Kumar VR, Verma SK. Vascular endothelial growth factor expression and angiogenesis in various grades and subtypes of meningioma. Indian $\mathrm{J}$ Pathol Microbiol. 2013;56(4):349-54.

31. Westendorf AM, Skibbe K, Adamczyk A, Buer J, Geffersb R, Hansen W, et al. Hypoxia enhances immunosuppression by inhibiting CD4+ effector $\mathrm{T}$ cell function and promoting Treg activity. Cell Physiol Biochem. 2017;41(4):1271-84. 